(2) OPEN ACCESS

\title{
Pinckney fracture: do not underestimate trauma of the distal phalanx of the hallux
}

\author{
João Nóbrega, ${ }^{1}$ Joana Ovídio, ${ }^{2}$ Joana Arcângelo, ${ }^{2}$ João Campagnolo ${ }^{2}$
}

${ }^{1}$ Serviço de Ortopedia, Hospital do Espirito Santo de Évora EPE, Evora, Portugal

${ }^{2}$ Serviço de Ortopedia Pediátrica, Hospital Dona Estefânia -

Centro Hospitalar Lisboa

Central, Lisboa, Portugal

Correspondence to

Dr João Nóbrega;

joaonobrega@campus.ul.pt

Accepted 29 August 2021

Check for updates

(C) BMJ Publishing Group Limited 2021. Re-use permitted under CC BY-NC. No commercial re-use. See rights and permissions. Published by BMJ.

To cite: Nóbrega J, Ovídio J, Arcângelo J, et al. BMJ Case Rep 2021;14:e244985. doi:10.1136/bcr-2021-

244985

\section{SUMMARY}

Toe injuries are common in the emergency department and most of them are treated conservatively. In some circumstances, these injuries can present as a physeal fracture with concomitant soft-tissue injury affecting the nail bed and resulting in a hidden open fracture. To adequately treat these patients, a high index of suspicion is needed to diagnose and treat the open fractures and to prevent complications such as infection, osteomyelitis, malunion and premature physeal arrest.

We report a case of a patient that was admitted to the hospital with a Salter-Harris type I fracture of the distal phalanx of the hallux. After confirming the diagnosis, antibiotic treatment was started and the fracture was reduced and fixed.

The literature on this entity is sparse and most of the management protocols are based on its hand equivalent-the Seymour fracture, emphasising the low threshold for treating these lesions as an open fracture.

\section{BACKGROUND}

This case report highlights that not every stubbed toe in the paediatric population is straightforward. Therefore, clinicians should be aware not only of the possibility of a physeal injury but also of the high probability of a nail bed soft tissue injury, resulting in an open fracture that requires early treatment to prevent morbidity and increased treatment costs.

\section{CASE PRESENTATION}

A 12-year-old patient was admitted to the emergency department of a paediatric hospital with pain and oedema of the hallux with partial nail detachment, following a stubbed trauma during martial arts practice. The radiographs were initially interpreted as negative because an oblique view was performed (figure 1) instead of a true lateral, which could have led to a misjudged diagnosis. Due to the high clinical suspicion the radiographic evaluation was promptly repeated. In the anteroposterior view, the physis appeared broadened compared with the contralateral toe (figure 2) and the lateral view clearly identified the dorsal displacement (figure 3).

Considering the imaging results, the patient was taken to the operating room (OR) and nail bed wound care, with irrigation and cleansing, was performed under a regional nerve block. Due to fracture reduction instability, a provisional transphalangeal fixation with a Kirschner wire was necessary (figure 4).

The patient was treated with antibiotics starting with intravenous cefazolin on the OR (hospital

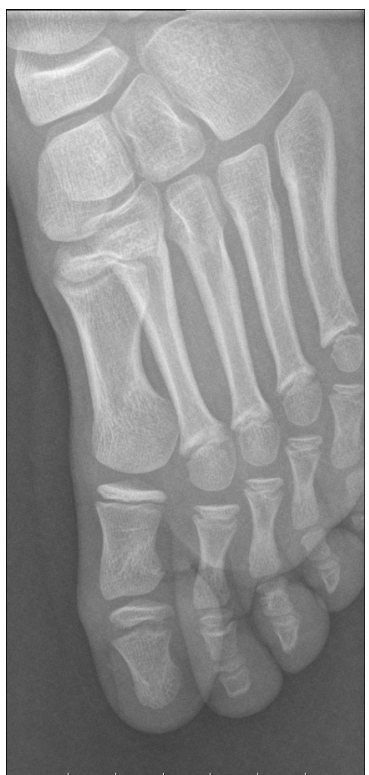

Figure 1 Oblique view misjudging the correct diagnosis.

policy) and with a regimen of oral amoxicillin/ clavulanic acid for 7 days after discharge.

\section{OUTCOME AND FOLLOW-UP}

The early management of this lesion, after discharge, required a close follow-up and a course of oral antibiotics. During the follow-up, the patient presented no clinical or radiographic signs of osteomyelitis which is considered the major complication, especially on the delayed treated lesions.

At the last outpatient follow-up, 1-year postinjury, the patient did not present any signs of early

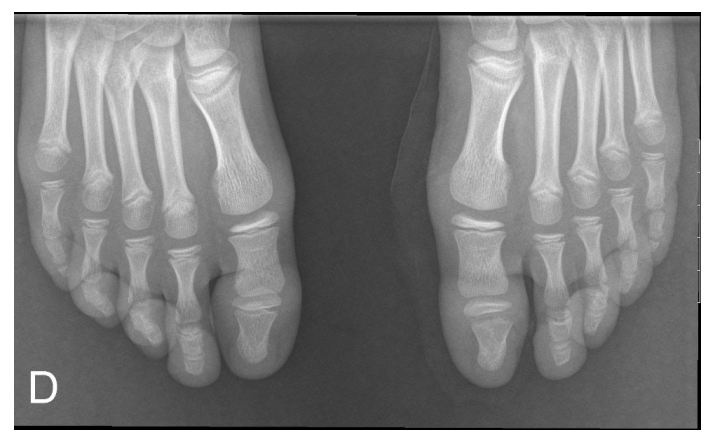

Figure 2 On AP view it is present a subtle widening of physeal space of distal phalanx of the toe; comparison with contralateral foot can be helpful. AP, anteroposterior; D, direita. 


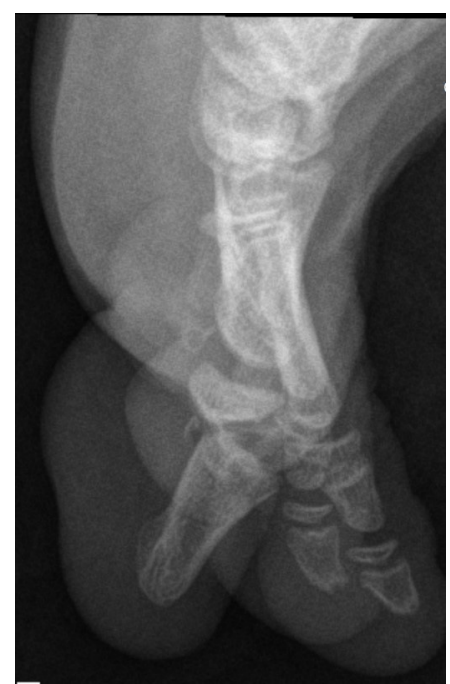

Figure 3 Lateral view shows a clear Salter Harris type I fracture of distal phalanx of the toe.

physeal arrest, neither pain with weight-bearing nor compromised normal function (figure 5).

\section{DISCUSSION}

The original description of this injury was initially highlighted by Pinckney $e \mathrm{al}^{1}$ and they describe them as a compound injury of a Salter Harris type I fracture that when mistreated evolved to an infection process of the toe.

These injuries result from a forced hyperflexion of the distal phalanx, which suggests that the vector of tension disrupts the dorsal toe structures. In fact, the layer of skin between nail and bone is the thinnest directly above the physis, where the germinal matrix of the nail (specialised inner layers of epidermis) and a shallow layer of dermis at the base of the nail would easily disrupt and allow the occurrence of an open physeal fracture. ${ }^{1-4}$

These lesions may be hidden from view because skin and toenails of the paediatric population are, in many cases, a very soiled region. For the same reason, the risk of contamination and infection is enhanced. Additionally, a late recognition and treatment makes it prone to complications such as cellulitis and osteomyelitis. ${ }^{1-4}$

Several signs should raise concern for this diagnosis: longer nail length or longer length of the lunula compared with the contralateral side, which indicates that the nail is positioned over

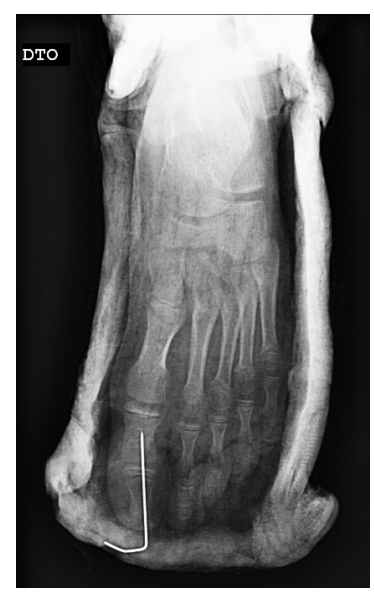

Figure 4 Reduction and transphalangeal fixation with Kirschner wire.
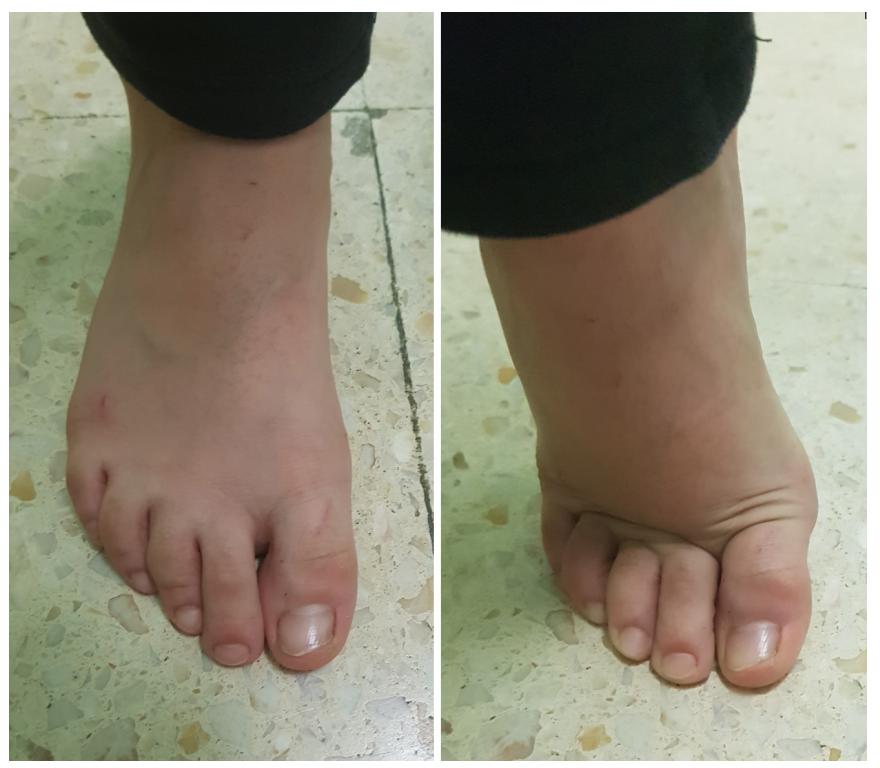

Figure 5 1-year postinjury: no compromise of normal function.

the nail fold; bleeding around the nail at time of injury ${ }^{4}$ and, laceration proximal to the nail fold. A physeal fracture on the distal phalanx should warn of an open fracture, unless proven otherwise. ${ }^{4}$ Clinicians should also be aware that lacerations of the nail and nail bed with an apparently normal radiograph, in the scenario of a hyperflexion mechanism, are manifestations of a possible Salter Harris type I fracture, and this should also be treated like an open injury.

This lesion should be treated according to the treatment protocol for open fractures, in a similar way as for Seymour fractures. That includes digital block, irrigation, debridement and antibiotic treatment. Despite the temptation to remove a partially avulsed nail, it should be kept in place as it adds stability to the fracture. ${ }^{5}$

In most cases, the fracture is not severely displaced, and the reduction is easy or even unnecessary, requiring only comfort measurements such as syndactyly or partial weight bearing.

In some cases, such as late presentation and severe displacement, the fracture can be unstable and require a provisional Kirschner wire fixation to maintain the reduction. In other cases,

Learning points

- Our case highlights the importance of being rigorous on radiographic evaluation. A true lateral and anteroposterior views are imperative for the correct diagnosis, especially in the presence of an occasional subtle presentation. When in doubt, compare with the contralateral foot.

- Early recognition is the key for a favourable outcome. Identifying these cases as open fractures with a regimen of antibiotics lowers the risk of cellulitis and osteomyelitis.

- Despite a negative radiographic evaluation, facing a nail outside the eponychium or a nail laceration, we should suspect of a physeal fracture; an open fracture must be assumed unless proven otherwise. When in doubt, treat it as an open injury. 
soft-tissue interposition (eg, germinal matrix) dictates surgical exploration. ${ }^{6}$

Treatment with antibiotics is required and the need for an initial intravenous therapy depends mainly on the clinical presentation. Patients with delayed treatment and infection signs require intraoperative cultures and benefit from initial intravenous antibiotic treatment. On the other side, for patients with early diagnosis a period of 5-7 days of oral antibiotics and close follow-up is accepted $^{7}$ (typically, a first-generation cephalosporin or clindamycin). Immobilisation in a postoperative/hard-soled shoe for 4 weeks is recommended.

Contributors JN planned, designed and wrote the manuscript in consultation with JO who helped in writing the case presentation section and with visual material (radiographs and photos). JA and JC contributed to the final version of the manuscript, by correcting the mistakes and giving theoretical concepts for the discussion.

Funding The authors have not declared a specific grant for this research from any funding agency in the public, commercial or not-for-profit sectors.

Competing interests None declared.
Patient consent for publication Obtained.

Provenance and peer review Not commissioned; externally peer reviewed.

Open access This is an open access article distributed in accordance with the Creative Commons Attribution Non Commercial (CC BY-NC 4.0) license, which permits others to distribute, remix, adapt, build upon this work non-commercially, and license their derivative works on different terms, provided the original work is properly cited and the use is non-commercial. See: http://creativecommons.org/ licenses/by-nc/4.0/.

\section{REFERENCES}

1 Pinckney LE, Currarino G, Kennedy LA. The stubbed great toe: a cause of occult compound fracture and infection. Radiology 1981;138:375-7.

2 Rathore MH, Tolymat A, Paryani SG. Stubbed great toe injury: a unique clinical entity. Pediatr Infect Dis J 1993;12:1034-5.

3 Noonan KJ, Saltzman CL, Dietz FR. Open physeal fractures of the distal phalanx of the great toe. A case report. J Bone Joint Surg Am 1994;76:122-5.

4 Kensinger DR, Guille JT, Horn BD, et al. The stubbed great toe: importance of early recognition and treatment of open fractures of the distal phalanx. J Pediatr Orthop 2001:21:31-4.

5 Krusche-Mandl I, Köttstorfer J, Thalhammer G, et al. Seymour fractures: retrospective analysis and therapeutic considerations. J Hand Surg Am 2013;38:258-64.

6 Morris B, Mullen S, Schroeppel P, et al. Open physeal fracture of the distal phalanx of the hallux. Am J Emerg Med 2017;35:1035.e1-1035.e3.

7 Abzug JM, Kozin SH. Seymour fractures. J Hand Surg Am 2013;38:2267-70.

Copyright 2021 BMJ Publishing Group. All rights reserved. For permission to reuse any of this content visit

https://www.bmj.com/company/products-services/rights-and-licensing/permissions/

BMJ Case Report Fellows may re-use this article for personal use and teaching without any further permission.

Become a Fellow of BMJ Case Reports today and you can:

- Submit as many cases as you like

- Enjoy fast sympathetic peer review and rapid publication of accepted articles

- Access all the published articles

Re-use any of the published material for personal use and teaching without further permission

Customer Service

If you have any further queries about your subscription, please contact our customer services team on +44 (0) 2071111105 or via email at support@bmj.com.

Visit casereports.bmj.com for more articles like this and to become a Fellow 